\title{
Alpha and beta diversity of phytoplankton in two subtropical eutrophic streams in southern Brazil
}

\author{
Karling Fernanda Schuster ${ }^{1 \star}$, Priscila Izabel Tremarin ${ }^{2}$ and Gilza Maria de Souza-Franco ${ }^{1,3}$
}

Received: March 16, 2015 Accepted: September 28, 2015

\begin{abstract}
This paper reports the alpha and beta diversity of phytoplankton communities of two streams differing in land use. We analyzed which environmental conditions affect diversity of the phytoplankton communities and tested the hypothesis that stream stretches protected by forests will have lower species richness, whereas higher beta-diversity would occur among the non-protected stretches. Samples were taken quarterly, from February to November 2012, in nine stretches, including four non-protected stretches, two partially protected stretches and three totally forest-protected stretches. Eleven abiotic variables and their coefficients of variation were analyzed. Phytoplankton was analyzed for species richness (alpha diversity), frequency of occurrence and beta-diversity. Species richness was calculated by first and second order jackknife indexes. Biotic data were submitted to Sørensen similarity analysis. A total of 429 infrageneric taxa were reported, representing $88 \%$ of the estimated expected species richness. The phytoplankton composition was typical for lotic environments with high richness values of Bacillariophyceae (66.0\%). High phytoplankton richness values occurred in all the sampled stretches, even though beta-diversity was moderate and indicated similarity between the sampled stretches, therefore only a part of the original hypothesis was corroborated.
\end{abstract}

Keywords: Diatomaceae, phytoplankton community, Preservation Unit, taxonomical composition, western region of the state of Santa Catarina

\section{Introduction}

Phytoplankton communities consist of photoautotrophic microorganisms (Reynolds 1984) suspended in aquatic environments that move passively due to the movements of winds and currents. Phytoplankton comprise a great diversity of species of a wide variety of forms and sizes, each with its own unique physiological requirements (Reynolds 2006). Information on phytoplankton communities (such as composition, structure, and spatial and temporal variability) in continental water ecosystems can elucidate the functioning of, and the energy flow within, these environments (Rodrigues 2004). Since phytoplankton communities respond rapidly to a wide variety of environmental disturbances (Cottingham \& Carpenter 1998; Lepistö et al. 2004; Paerl \& Huisman 2009) and present a high diversity of species in natural conditions (Hutchinson 1961; 1976; Reynolds 1984; 2006), they can serve as important indicators of environmental disarray.

River algae are controlled by different factors than phytoplankton in lentic habitats, such as physical (light, temperature), chemical (gases, inorganic nutrients, ions) and biotic (herbivory) variables, and their responses, in contrast to species in lentic waters, are mainly affected by river flow. Anthropogenic activities (disposal of organic wastes and removal of riparian vegetation) may cause significant changes to phytoplankton communities (Leland \& Porter 2000; Lewis et al. 2001; Munn et al. 2002). In fact, species richness may be the simplest method to assess and quantify the complexity of a given environment (Nabout et al. 2007). Since it is coupled to taxonomic composition, species richness provides a measure of the main components of biological diversity for characterizing an ecosystem and, thus, is important for defining preservation strategies (Nogueira et al. 2008). Consequently, species diversity is a quality of biological communities that is deeply related to stability, productivity, trophic structure and migratory processes (Stirling \& Wilsey 2001).

Alpha-diversity and beta-diversity have been employed to determine patterns of species diversity (Whittaker 1972; Legendre et al. 2005), where $\alpha$-diversity is defined as the local diversity (within the community) and thus a meas-

\footnotetext{
${ }^{1}$ Programa de Pós-graduação em Ciências Ambientais, Universidade Comunitária Regional de Chapecó, Senador Atílio Fontana, 591 E - Efapi, 89809-000, Chapecó, SC, Brazil

${ }^{2}$ Departamento de Botânica, Universidade Federal do Paraná, Jardim das Américas, P.O. Box 19031, 81531-980, Curitiba, PR, Brazil

${ }^{3}$ Universidade Federal da Fronteira Sul, Campus Realeza, PR 182 km 466, 85770-000, Edmundo Gaievski, 1000, Realeza PR Brazil

* Corresponding author: karlingfe@gmail.com
} 
ure of richness, whereas $\gamma$-diversity (regional diversity) represents the total number of sampled species (Whittaker 1972). Beta-diversity encompasses the differences in species composition of different sites. It is thus a simple method to characterize species heterogeneity of a given region (Whittaker 1972; Gering et al. 2003). In contrast to species richness (alpha-diversity), beta-diversity tests hypotheses about the patterns of distribution of species biodiversity among different places (Baselga 2010).

There have been very few studies on phytoplankton beta-diversity in Brazil. Of these, the studies of Huszar et al. (1990), Nabout et al. (2007), Nogueira et al. (2008), Nogueira et al. (2010) and Pires (2014) should be highlighted, although these studies only evaluated alpha- and beta-diversity in lentic environments.

The current paper assesses variation in alpha- and betadiversity of species of phytoplankton in two streams with different land use and levels of occupation, and analyzes whether changes, such as in environmental conditions, affect phytoplankton diversity. Specifically, this paper tests the hypothesis that stream stretches protected by the forest will have lower species richness, whereas nonprotected stretches will have higher beta-diversity. The influence of physical and chemical variables of the water on the components of alpha- and beta-diversity of algae will also be tested.

\section{Materials and methods}

The hydrographical region under study lies in the western region of the state of Santa Catarina, Brazil, on the border between the municipalities of Chapecó and Guatambu, and comprises an area of the most salient agricultural activities in the state. The area can be divided into two hydrographic microbasins, namely the Tigre River and the Retiro Stream. The cultivation of bean, soybean and corn, and the breeding of swine, broilers and livestock, on small farms are the main agricultural activities in these two micro basins.

The microbasin of the Tigre River has almost $20 \%$ of its area covered by the preservation unit 'Floresta Nacional de Chapecó' (FLONA), Chapecó, SC, Brazil. Six sampling sites (P1 to P6) were selected throughout the length of the Tigre River. The first two sites (P1 and P2) are not protected by forest and lie upstream in an area subjected to human impacts. P3 lies in an area of transition between forest and the agricultural area upstream, whereas sites P4, P5 and P6 lie within the forest and are protected by it. The Retiro Stream only borders the forest and has three sampling sites: P7 is upstream of the forest, and P8 and P9 have only one of their margins protected by the forest (Fig. 1). Table 1 provides the geographic sites on the stretches analyzed, and the characteristics of each site.

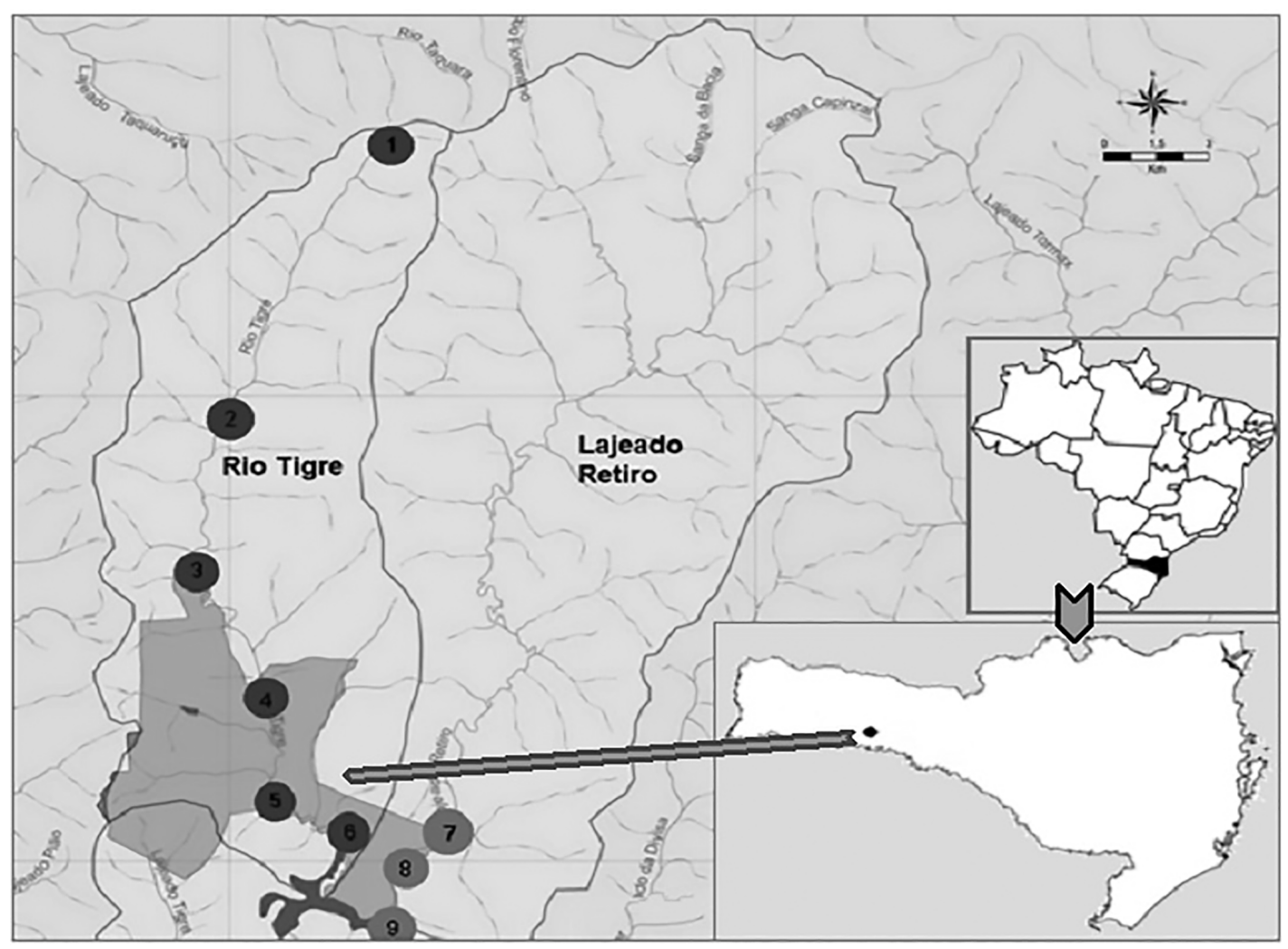

Figure 1. Sampling sites on the river Tigre and stream Retiro in the western region of the state of Santa Catarina, Brazil, between February and November 2012. Source: ICMBio, 2013. 
Table 1. General characteristics of the sampled sites. Localization by geographic coordinates, altitude, mean depth, mean width of the streams and discharge $\left(\mathrm{m}^{3} / \mathrm{s}\right)$ in the stretches under analysis.

\begin{tabular}{|c|c|c|c|c|c|c|c|c|}
\hline Stream & $\begin{array}{l}\text { Identification of } \\
\text { the sampled site }\end{array}$ & $\begin{array}{l}\text { Geographic } \\
\text { coordinates }\end{array}$ & $\begin{array}{l}\text { Altitude } \\
(\mathrm{m})\end{array}$ & $\begin{array}{c}\text { Mean } \\
\text { depth }(m)\end{array}$ & $\begin{array}{c}\text { Mean } \\
\text { width }(\mathrm{m})\end{array}$ & $\begin{array}{l}\text { Discharge } \\
\left(\mathbf{m}^{3} \cdot \mathbf{s}^{-1}\right)\end{array}$ & $\begin{array}{l}\text { Order } \\
\text { stream }\end{array}$ & Additional observations \\
\hline \multirow{6}{*}{ Tigre } & P1 & $\begin{array}{l}27^{\circ} 01^{\prime} 07^{\prime \prime} \mathrm{S} / \\
52^{\circ} 45^{\prime} 46^{\prime \prime} \mathrm{W}\end{array}$ & 613 & 0.2 & 3.0 & 0.12 & $1^{a}$ & $\begin{array}{l}\text { Small strip of riparian vegetation, adjacent } \\
\text { areas with corn crops. }\end{array}$ \\
\hline & P2 & $\begin{array}{l}27^{\circ} 02^{\prime} 50^{\prime \prime} \mathrm{S} / \\
52^{\circ} 46^{\prime} 37^{\prime \prime} \mathrm{W}\end{array}$ & 586 & 0.2 & 2.7 & 0.36 & $3^{\mathrm{a}}$ & $\begin{array}{l}\text { Strip of non-extant riparian vegetation; } \\
\text { adjacent areas planted with eucalyptus and } \\
\text { mate trees; marked erosion process. }\end{array}$ \\
\hline & P3 & $\begin{array}{l}27^{\circ} 04^{\prime} 11 " \mathrm{~S} / \\
52^{\circ} 46^{\prime} 50^{\prime \prime} \mathrm{W}\end{array}$ & 583 & 0.3 & 4.8 & 0.37 & $3^{\mathrm{a}}$ & $\begin{array}{l}\text { Small strip of riparian vegetation; transition } \\
\text { area between pastureland and preserved forest. }\end{array}$ \\
\hline & P4 & $\begin{array}{l}27^{\circ} 05^{\prime} 39^{\prime \prime} \mathrm{S} / \\
52^{\circ} 46^{\prime} 10^{\prime \prime} \mathrm{W}\end{array}$ & 560 & 0.4 & 4.8 & 0.50 & $3^{\mathrm{a}}$ & $\begin{array}{c}\text { Preserved riparian vegetation, area protected } \\
\text { by the forest }\end{array}$ \\
\hline & P5 & $\begin{array}{l}27^{\circ} 06^{\prime} 05^{\prime \prime} \mathrm{S} / \\
52^{\circ} 46^{\prime} 12^{\prime \prime} \mathrm{W}\end{array}$ & 545 & 0.3 & 4.9 & 0.57 & $3^{\mathrm{a}}$ & $\begin{array}{c}\text { Preserved riparian vegetation, area protected } \\
\text { by the forest }\end{array}$ \\
\hline & P6 & $\begin{array}{l}27^{\circ} 06^{\prime} 37^{\prime \prime} \mathrm{S} / \\
52^{\circ} 45^{\prime} 29^{\prime \prime} \mathrm{W}\end{array}$ & 539 & 0.3 & 9.5 & 0.59 & $4^{\mathrm{a}}$ & $\begin{array}{l}\text { Preserved riparian vegetation, area } \\
\text { protected by the forest, low water velocity; } \\
\text { river's mouth. }\end{array}$ \\
\hline \multirow{3}{*}{ Retiro } & P7 & $\begin{array}{l}27^{\circ} 05^{\prime} 05^{\prime \prime} \mathrm{S} / \\
52^{\circ} 43^{\prime} 55^{\prime \prime} \mathrm{W}\end{array}$ & 560 & 1.2 & 8.5 & 0.29 & $4^{\mathrm{a}}$ & $\begin{array}{l}\text { Lack of riparian vegetation, modified } \\
\text { river course with small barrages. }\end{array}$ \\
\hline & P8 & $\begin{array}{l}27^{\circ} 06^{\prime} 46^{\prime \prime} \mathrm{S} / \\
52^{\circ} 45^{\prime} 01^{\prime \prime} \mathrm{W}\end{array}$ & 542 & 0.3 & 8.3 & 1.17 & $4^{\mathrm{a}}$ & $\begin{array}{l}\text { Left margin protected by the forest; right } \\
\text { margin with a small strip of riparian } \\
\text { vegetation; adjacent area with crops; } \\
\text { stretch with small rapids }\end{array}$ \\
\hline & P9 & $\begin{array}{l}27^{\circ} 07^{\prime} 17^{\prime \prime} \mathrm{S} / \\
52^{\circ} 45^{\prime} 06^{\prime} \mathrm{W}\end{array}$ & 540 & 1.2 & 6.8 & 1.26 & $4^{\mathrm{a}}$ & $\begin{array}{l}\text { Left margin protected by the forest; adjacent } \\
\text { areas with pastureland, erosion } \\
\text { processes; river's mouth }\end{array}$ \\
\hline
\end{tabular}

\section{Sampling}

Sub-surface samplings were made at the nine sampling sites during February (summer), May (autumn), August (winter) and November (spring) of 2012. Data on latitude, longitude, elevation (GPS - Garmin Etrex H), river width and depth (measuring tape), and river discharge (floating method, EPA 1997) were recorded at each sampling site.

Samples were collected by successive horizontal hauls with $20 \mu \mathrm{m}$ mesh nets, and fixed with $4 \%$ formaldehyde solution analysis of species richness. Species were identified using an optical microscope with magnifications of 400x and 1000x. Eight slides per sample were analyzed, for a total of 32 slides per sampling site. Classification followed: Round (1971) for classes of Chlorophyta; Komárek \& Anagnostidis $(1989 ; 1998 ; 2005)$ and Hoffmam et al. (2005) for Cyanobacteria; and Hoek et al. (1995) for the other classes. Identification to genus and species were performed using the specialized works of Komárek \& Fott (1983), Sant'Anna (1984), Nogueira (1991), Comas (1996), Godinho (2009), Godinho et al. (2010), Rodrigues et at. (2010), Rosini et al. (2012; 2013a), and Ramos et al. (2012) for green algae; Hüber-Pestalozzi (1955), Tell \& Conforti (1986), and Menezes (1994) for Euglenophyceae; Castro et al. (1991), and Menezes (1994) for Cryptophyceae; Komár-
ková-Legnerová \& Cronberg (1994), Azevedo et al. (1996), Azevedo \& Sant’Anna (1999; 2003), Komárek \& Azevedo (2000), Sant'Anna et al. (2004), and Rosini et al. (2013b) for Cyanobacteria; Krammer \& Lange-Bertalot (1986; 1988; 1991), Metzeltin \&Lange-Bertalot (1998; 2007), and Metzeltin et al. (2005) for Bacillariophyceae; Sant'Anna et al. (1989), Ferragut et al. (2005), Tucci et al. (2006), and Sant'Anna et al. (2012) for the overall community. Updating of the taxonomy followed An et al. (1999), Hegewald (1997; 2000), Hegewald \& Hanagata (2000), Hegewald \& Wolf (2003), Krienitz et al. (2003), Buchheim et al. (2005), and Krienitz \& Bock (2012). Samples were deposited in the herbarium of the Universidade Comunitária Regional de Chapecó.

Abiotic variables, such as water temperature and dissolved oxygen (oximeter HANNA HI 9146), were also measured. An aliquot of water was retrieved for measuring $\mathrm{pH}$ (digital pHmeter Thermo Scientific Orion 4 Start), electrical conductivity and total dissolved solids (multi-parameter water quality monitoring system, Orion), turbidity (turbidity meter Hach $2100 \mathrm{~N}$ ), total alkalinity (titration meter method), total nitrogen (APHA 2012), total phosphorus (Goltermam et al. 1978), biochemical oxygen demand (BOD respiration meter method) and chlorophyll-a (APHA 2012). 


\section{Data analysis}

Means, standard deviations and amplitudes were calculated for the physical and chemical variables of the water from the seasonal samplings at each collection site. The trophic level of the site was analyzed for phosphorus and chlorophyll-a concentrations, following Lampareli (2004). One-way analysis of variance (ANOVA) was used to evaluate differences among sampling sites with each sampling site being treated as an independent variable. The physical and chemical variables were treated as the response variables with each seasonal sampling as a replication for the sampling sites. Physical and chemical variables with significant differences $(\mathrm{p}<0.05)$ were correlated with alpha- and beta-diversity.

The species richness of each sampling site (alphadiversity) was determined from the number of species collected throughout the entire study period, taking into consideration data from qualitative analysis, and was estimated by first and second order jackknife indexes (Nabout et al. 2007) with StimateS (Colwell 2006). Occurrence frequencies were categorized as: constant for species found in more than $50 \%$ of the collections; common when found between $25 \%$ and $50 \%$ of the collections; and accidental or rare species when found in less than $25 \%$ of the collections (Lobo \& Leighton 1986).

The $\beta$-1-diversity index (Harrison et al. 1992) measures the amount that regional diversity exceeds mean alphadiversity, and is calculated by the formula $\beta-1=\left[\left(\mathrm{S} / \alpha_{\text {mean }}\right)-1\right] /$ $[\mathrm{N}-1] \times 100$, where $S$ is the regional diversity or total richness (the number of species per each sampling site); $\alpha_{\text {mean }}$ is the mean alpha diversity (mean number of species) for each site in each period; $\mathrm{N}$ is the number of sites of the period.

The $\beta-1$ index varies between 0 and 100 , with 100 indicating a set of dissimilar sampling sites and 0 indicating a set of totally similar sampling sites. Beta-diversity over $50 \%$ indicates high heterogeneity in phytoplankton composition among systems; between 20 and $50 \%$ indicates intermediate heterogeneity; and below $20 \%$ indicates low heterogeneity (Harrison et al.1992; Nabout et al. 2007).

Floral similarity between sites was measured by Sørensen's similarity index (Magurran 1988). Similarity in phytoplankton composition among sites was determined using cluster analyses with Sørensen's distance, employing the UPGMA-type method (mean of groups). Analysis was performed using PC-ORD (McCune \& Mefford 1999) and the reliability of the dendrogram was assessed by the coefficient of the co-phenetic co-relationship with PAST (Hammer et al. 2001). This analysis was employed to increase the reliability of the conclusions drawn from the interpretation of the dendrogram (Kopp et al. 2007).

\section{Results}

Phosphorus concentrations for the Tigre River (mean 0.2 mg. $\left.\mathrm{L}^{-1}( \pm 0.1)\right)$ and for the Retiro Stream $\left(0.3 \pm 0.2 \mathrm{mg} . \mathrm{L}^{-1}\right)$ classified the sampling stretches of P1, P2, P3, P4, P5, P7 and P8 as eutrophic and P6 and P9 as super-eutrophic, with no significant difference between the sites $(\mathrm{p}>0.05)$. However, analysis of the concentration of chlorophyll-a in the

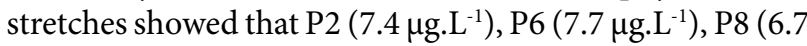
$\left.\mu \mathrm{g} . \mathrm{L}^{-1}\right)$ and $\mathrm{P} 9\left(21.1 \mu \mathrm{g} . \mathrm{L}^{-1}\right)$ were super-eutrophic (Tab. 2). All the sampling sites had a $\mathrm{pH}$ close to neutral and were well oxygenated, (between 5.5 and $9.8 \mathrm{mg} \cdot \mathrm{L}^{-1}$ ). Turbidity for the stretches of the Retiro Stream were higher than those for the Tigre River $\left(\mathrm{F}_{(2.33)}=9.6964 ; \mathrm{p}=0.0005\right)$. Rates for Electrical conductivity, total dissolved solids and total alkalinity in the upstream sections of the rivers were higher than those in sections further downstream (river mouth) (Tab. 2), and the differences among sites in total alkalinity were significant $\left(\mathrm{F}_{(2.33)}=4.5393 ; \mathrm{p}=0.0181\right)$. The total number of infrageneric taxa of the phytoplankton communities of both rivers was 429 . This amount corresponded to $88 \%$ of the estimated expected richness (Jackknife $1=491$ sp; Jackknife $2=501 \mathrm{sp}$ ) (Fig. 2). The phytoplankton community comprised nine classes among which the most represented were Bacillariophyceae (283 taxa) Chlorophyceae (47 taxa), Zygnemaphyceae (36 taxa), Cyanophyceae (35 taxa), followed by Euglenophyceae (17 taxa), Xanthophyceae (five taxa), Chrysophyceae (three taxa), Dinophyceae (two taxa) and Chryptophyceae (one taxon) (Fig. 3). Bacillariophyceae had the greatest richness at all sampling sites.

Fifty-nine out of the 429 taxa had constant occurrence (relative occurrence frequency - FR\% above 51\%); 91 taxa were common (between 25 and 50\%) and 279 taxa were rare (lower than 24\%). Further, $96 \%$ of the 59 taxa with constant occurrence were specimens of the class Bacillariophyceae, whereas the others (4\%) comprised the species Pediastrum duplex var. duplex and Desmodesmus communis, both of the class Chlorophyceae. Of Cyanophyceae, the greatest occurrence was Microcystis aeruginosa (42\%), a potentially toxin-producing species. The Bacillariophyceae comprised Amphipleura chiapasensis, Cymbella aspera, Melosira varians, Navicula cryptocephala, N. rostellata, N. simulata, N. germainii, Nitzschia palea, N. recta, Ulnaria ulna, Achnanthidium minutissimum, Aulacoseira pusilla, A. calypsi, Gyrosigmascalproides, G. acuminatum, G. nodiferum, Luticola acidoclinata and Gomphonema parvulum, which occurred in at least $80 \%$ of the collected samples.

Species richness (alpha-diversity) ranged between 248 taxa at P1 and 147 taxa at P3 (Fig. 4), with a decreasing gradient in the number of taxa from the river source to its mouth in both rivers. The beta-diversity index was applied to quantify renewal or substitution of the species among sites. In fact, the $\beta-1$ diversity index for the period under analysis ranged between 23.8 (P1 and P7) and 38.9 (P9) (Fig. 4) and indicated an intermediate level of similarity among the sampled environments.

Sorensen's similarity analysis revealed two groups of taxa (Fig. 5), with a similarity of 60\%: sampling sites P1, P2 and $\mathrm{P} 7$ were the most similar in phytoplankton composition, followed by P3, P4 and P5. Sites P8, P6 and P9 were dis- 
Table 2. Means, standard deviation (in brackets) and amplitude of physical and chemical characteristics of stream water measured at the subsurface of each sampled site throughout the four sampled periods. Water $\mathrm{T}=$ Water temperature; $\mathrm{pH}=$ hydrogenionic potential; $\mathrm{DO}=$ dissolved oxygen; $\mathrm{BOD}=\mathrm{Biochemical} \mathrm{Oxygen}$ Demand; TN = total nitrogen; TP = total phosphorus; EC = Electrical conductivity; Talk = total alkalinity; TDS = total dissolved solids; Turb = turbidity.

\begin{tabular}{|c|c|c|c|c|c|c|c|c|c|}
\hline $\begin{array}{l}\text { Physical and chemical } \\
\text { chacacteristics }\end{array}$ & $\mathrm{P} 1$ & P2 & P3 & $\mathrm{P} 4$ & P5 & P6 & P7 & P8 & P9 \\
\hline \multirow[b]{2}{*}{ Water $\mathrm{T}\left({ }^{\circ} \mathrm{C}\right)$} & $21.1( \pm 3.2)$ & $18.5( \pm 3.8)$ & $19.8( \pm 3.9)$ & $18.2( \pm 3.1)$ & $18.3( \pm 3.7)$ & $21.0( \pm 4.3)$ & $20.7( \pm 4.7)$ & $19.6( \pm 3.1)$ & $20.3( \pm 4.7)$ \\
\hline & $17.6-25.0$ & $15.0-22.6$ & $14.5-23.7$ & $14.4-22.0$ & $13.9-23.0$ & $17.7-27.0$ & $14.8-26.0$ & $15.5-23.0$ & $15.0-26.0$ \\
\hline \multirow{2}{*}{$\mathrm{pH}$} & $7.3( \pm 0.1)$ & $7.2( \pm 0.1)$ & $7.2( \pm 0.1)$ & $7.0( \pm 0.06)$ & $7.1( \pm 0.1)$ & $7.3( \pm 0.5)$ & $6.9( \pm 0.03)$ & $7.2( \pm 0.1)$ & $7.7( \pm 0.9)$ \\
\hline & $7.2-7.5$ & $7.1-7.3$ & $7.1-7.4$ & $6.9-7.1$ & $6.9-7.1$ & $7.0-8.0$ & $6.8-6.9$ & $7.1-7.4$ & $7.1-9.2$ \\
\hline \multirow{2}{*}{$\mathrm{DO}\left(\mathrm{mg} \cdot \mathrm{L}^{-1}\right)$} & $7.6( \pm 1.5)$ & $6.9( \pm 0.7)$ & $7.4( \pm 0.6)$ & $6.93( \pm 0.4)$ & $7.0( \pm 0.8)$ & $7.7( \pm 0.6)$ & $6.5( \pm 0.8)$ & $6.9( \pm 0.4)$ & $8.03( \pm 0.4)$ \\
\hline & $6.4-9.8$ & $5.5-7.4$ & $6.6-7.9$ & $6.4-7.4$ & $6.2-8.1$ & $6.7-8.2$ & $5.7-7.7$ & $6.6-7.6$ & $7.5-8.4$ \\
\hline \multirow{2}{*}{ BOD $\left(\mathrm{mg} \cdot \mathrm{L}^{-1}\right)$} & $1.9( \pm 1.1)$ & $1.3( \pm 1.0)$ & $1.6( \pm 1.2)$ & $2.0( \pm 1.4)$ & $2.8( \pm 0.7)$ & $1.7( \pm 1.6)$ & $1.2( \pm 1.2)$ & $3.1( \pm 1.7)$ & $2.0( \pm 1.7)$ \\
\hline & $0.7-2.9$ & $0.6-2.4$ & $0.3-2.5$ & $0.6-3.4$ & $2.0-3.3$ & $0.0-3.3$ & $0.0-2.5$ & $0.9-5.1$ & $0.3-3.5$ \\
\hline \multirow{2}{*}{ TN (mg.L $\left.L^{-1}\right)$} & $0.6( \pm 0.8)$ & $0.3( \pm 0.1)$ & $1.1( \pm 1.7)$ & $0.7( \pm 0.8)$ & $0.5( \pm 0.6)$ & $0.7( \pm 0.8)$ & $2.4( \pm 3.7)$ & $1.2( \pm 0.7)$ & $1.0( \pm 0.6)$ \\
\hline & $0.0-1.7$ & $0.2-0.4$ & $0.0-3.7$ & $0.0-1.5$ & $0.0-1.4$ & $0.1-1.9$ & $0.3-8.0$ & $0.5-2.1$ & $0.4-1.5$ \\
\hline \multirow[b]{2}{*}{$\mathrm{TP}\left(\mathrm{mg} \cdot \mathrm{L}^{-1}\right)$} & $0.2( \pm 0.1)$ & $0.2( \pm 0.1)$ & $0.2( \pm 0.1)$ & $0.2( \pm 0.1)$ & $0.1( \pm 0.1)$ & $0.3( \pm 0.5)$ & $0.3( \pm 0.4)$ & $0.2( \pm 0.2)$ & $0.3( \pm 0.4)$ \\
\hline & $0.06-0.43$ & $0.06-0.25$ & $0.08-0.33$ & $0.08-0.43$ & $0.00-0.25$ & $0.00-1.02$ & $0.06-0.83$ & $0.08-0.54$ & $0.06-0.97$ \\
\hline \multirow{2}{*}{$\mathrm{EC}\left(\mu \mathrm{S} . \mathrm{cm}^{-1}\right)$} & $83.6( \pm 18.2)$ & $66.5( \pm 17.1)$ & $64.0( \pm 18.6)$ & $61.2( \pm 16.7)$ & $58.3( \pm 15.4)$ & $43.4( \pm 4.3)$ & $65.2( \pm 26.6)$ & $64.0( \pm 14.5)$ & $54.8( \pm 17.1)$ \\
\hline & $68.0-106.7$ & $48.6-86.7$ & $46.2-86.7$ & $46.9-83.0$ & $45.8-78.2$ & $38.5-48.5$ & $50.1-105.0$ & $49.1-80.5$ & $39.8-79.5$ \\
\hline \multirow[b]{2}{*}{ TDS (mg. $\left.\mathrm{L}^{-1}\right)$} & $39.7( \pm 9.0)$ & $31.5( \pm 8.0)$ & $30.5( \pm 8.6)$ & $28.7( \pm 7.9)$ & $27.7( \pm 7.3)$ & $21.0( \pm 2.1)$ & $30.7( \pm 12.8)$ & $31.0( \pm 8.1)$ & $25.7( \pm 7.8)$ \\
\hline & $32.0-51.0$ & $23.0-41.0$ & $22.0-41.0$ & $22.0-39.0$ & $22.0-37.0$ & $18.0-23.0$ & $23.0-50.0$ & $23.0-41.0$ & $19.0-37.0$ \\
\hline \multirow{2}{*}{ Turb (NTU) } & $7.8( \pm 3.2)$ & $9.6( \pm 3.9)$ & $7.6( \pm 0.6)$ & $7.56( \pm 1.3)$ & $10.6( \pm 1.4)$ & $14.5( \pm 5.1)$ & $22.6( \pm 4.4)$ & $18.2( \pm 10.7)$ & $14.1( \pm 4.6)$ \\
\hline & $3.2-10.6$ & $6.4-15.3$ & $6.8-8.2$ & $6.1-8.9$ & $8.6-11.8$ & $8.3-20.1$ & $18.6-27.3$ & $10.8-34.2$ & $10.7-20.8$ \\
\hline \multirow[b]{2}{*}{ Talk (mg.L $\left.\mathrm{L}^{-1} \mathrm{CaCO}_{3}\right)$} & $27.3( \pm 4.4)$ & $22.3( \pm 4.1)$ & $19.5( \pm 2.5)$ & $18.1( \pm 2.5)$ & $17.0( \pm 2.6)$ & $17.7( \pm 4.1)$ & $17.8( \pm 2.7)$ & $17.3( \pm 4.1)$ & $15.5( \pm 2.6)$ \\
\hline & $22.0-32.8$ & $18.7-28.3$ & $17.3-22.8$ & $15.5-20.4$ & $14.5-19.4$ & $15.0-23.7$ & $15.5-21.6$ & $14.0-22.7$ & $13.0-19.0$ \\
\hline \multirow{2}{*}{ Chlorophyll a $\left(\mu \mathrm{g} . \mathrm{L}^{-1}\right)$} & $1.1( \pm 2.2)$ & $7.4( \pm 8.3)$ & $0.1( \pm 0.2)$ & $0.2( \pm 0.3)$ & $0.1( \pm 0.3)$ & $7.7( \pm 12.0)$ & $1.9( \pm 1.5)$ & $6.7( \pm 5.0)$ & $21.1( \pm 3.2)$ \\
\hline & $00-453$ & $0.0-16.4$ & $0.0-0.5$ & $0.0-0.7$ & $0.0-0.6$ & $0.0-25.5$ & $0.0-3.8$ & $27-133$ & $02-299$ \\
\hline
\end{tabular}

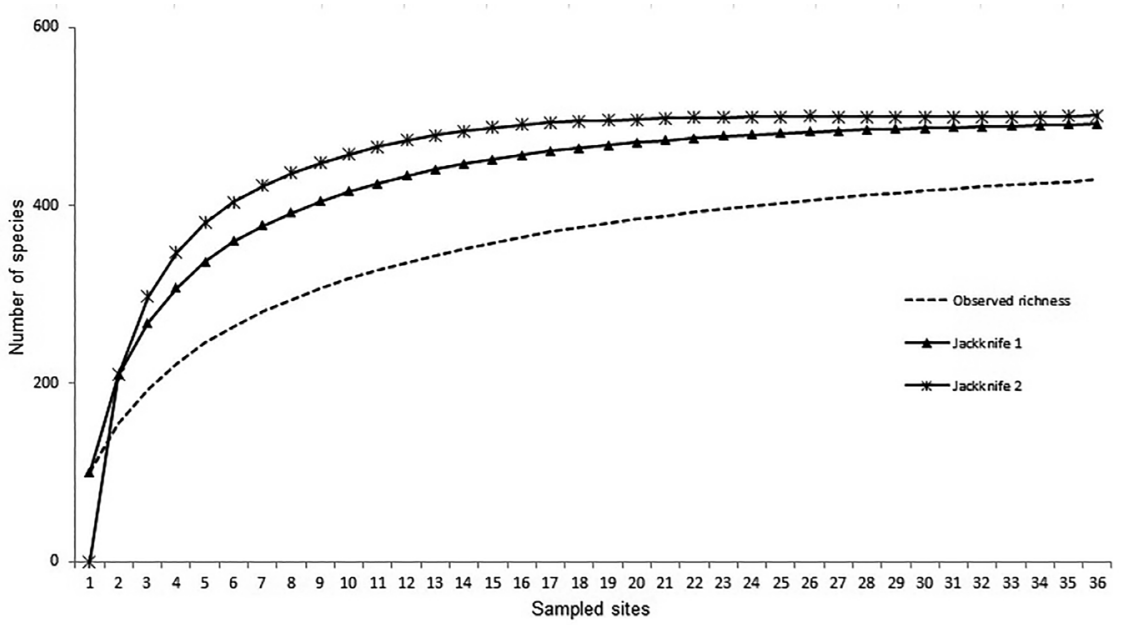

Figure 2. Species rarefaction curve for the 36 sampled sites between February and November 2012 on the streams Tigre and Retiro, western Santa Catarina, Brazil. 


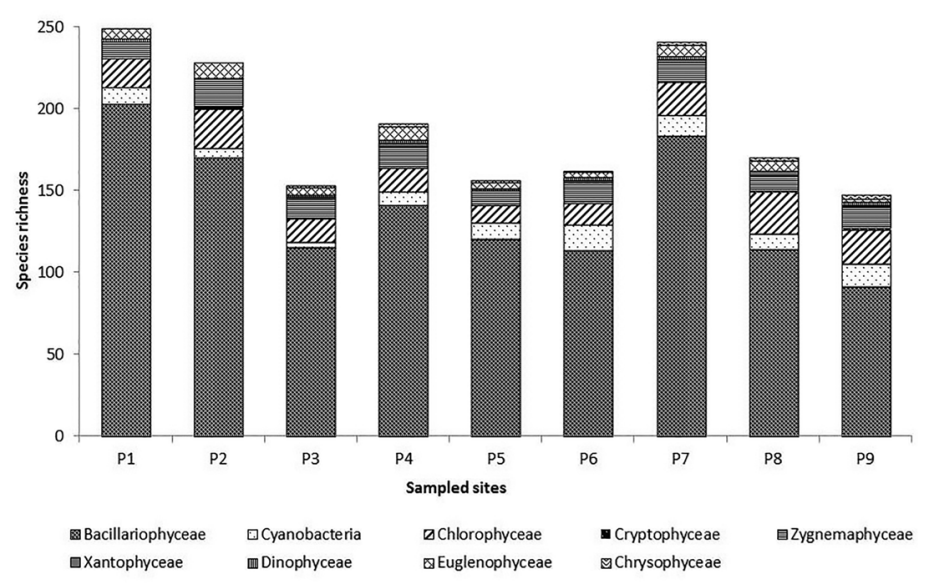

Figure 3. Number of species per sampling sites during the study period (gamma diversity), distributed in taxonomic classes in each sampled river stretch.

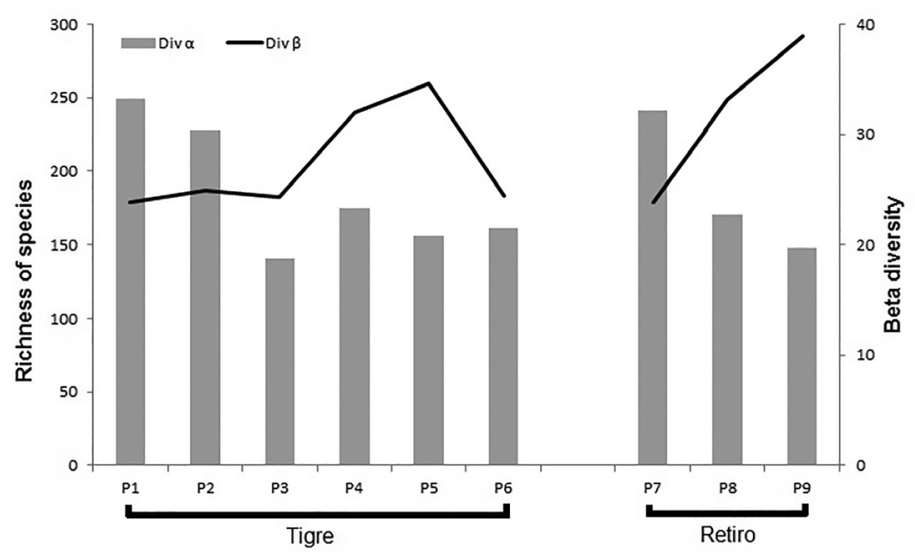

Figure 4. Species richness (alpha diversity) and beta diversity for each sampling site on the streams Tigre and Retiro, western Santa Catarina, Brazil, between February and November 2012.

\begin{tabular}{lcccc}
0.038 & 0.182 & 0.326 & 0.469 & 0.613 \\
100 & 75 & 50 & 25 & 0 \\
\hline
\end{tabular}

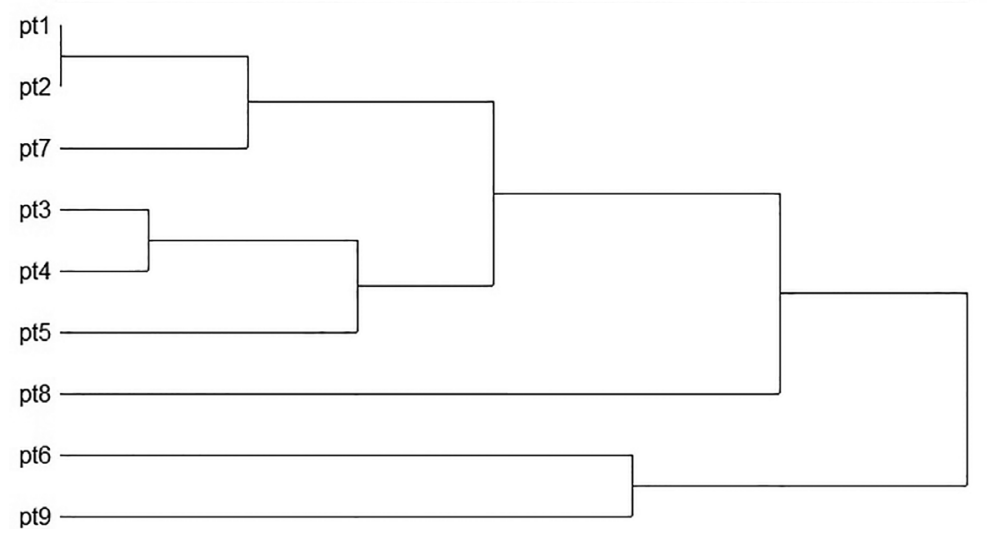

Figure 5. Dendrogram of Sørensen coefficient of similarity based on the floristic inventory of each sampling site. Co-phenetic Coefficient $(\mathrm{r})=0.86$. pt $1=\operatorname{site} 1$; pt2 = site 2; pt3 = site $3 ; \mathrm{pt} 4=$ site $4 ; \mathrm{pt} 5=$ site $5 ; \mathrm{pt} 6=$ site $6 ; \mathrm{pt} 7=$ site 7 ; pt $8=$ site $8 ; \mathrm{pt} 9=$ site 9 . 
similar to all the other sites. However, similarity coefficients at the sites ranged between 0.038 and 0.613 , which revealed high flora similarity. Since the phytoplankton composition among the sites was very similar, it reinforced the low heterogeneity found for beta-diversity among the stretches. The co-phenetic coefficient rate was $r=0.86$.

\section{Discussion}

As a whole, the hydrographical region exhibited high phytoplankton richness with 429 registered taxa or rather, $88 \%$ of the expected richness. These results show that the sampling effort was successful at representing the richness present and in indicating consistent patterns of diversity. Although rarely employed in studies on phytoplankton, the jackknife indexes of the first and second orders (Nabout et al. 2007; Nogueira et al. 2008) were an important tool for assessing the efficacy of the sampling effort. It should be emphasized that closeness between the observed and the estimated expected species richness indicates that the sampling effort was adequate to reveal the diversity of phytoplankton in the two study rivers (Nogueira et al. 2010).

According to Vannote et al. (1980), a hypothetical longitudinal profile can be identified in rivers in which it is expected that there would be a lower amount of suspended substances and a lower nutrient load in the stretches closer to a river's source. The conditions of the two study-rivers were far from this prediction. The highest rates for electrical conductivity, total alkalinity and total dissolved solids were reported in the stretches closest to the source, whereas phosphorus load did not vary among all of the sampling sites. This fact indicates that, regardless of a stretch being protected or not by the forest, exposure to human interference occurs at some level. The environment's trophic level may have contributed to the high richness of algae along the rivers since phosphorus is usually a limiting resource for primary productivity (Ternus et al. 2011). The de-characterization of the longitudinal profile may be attributed to land use and occupation in the areas close to the sources of the two rivers, where crop cultivation and intensive animal breeding predominate and the streams are not protected by riparian vegetation. The current investigation shows the importance of surface drainage in contributing electrolytes, which were much higher in the stretches close to the sources of the rivers. Research by Ternus et al. (2011) showed that nitrogen and phosphorus concentrations in lotic environments can be greatly affected by the use and occupation of the soil by agricultural activities.

Bacillariophyceae and Chlorophyceae were the two taxonomic classes with the greatest number of species recorded out of the nine classes encountered during the study. These groups are usually found in limnic environments and their occurrence demonstrates their ability to adapt to water fluxes. Similar results were reported in other Brazilian rivers by Monteiro et al. (2009) and Rodrigues et al. (2009), who reported that Diatomaceae, Chloroficeae and groups of cyanobacteria were the most abundant taxa. Although, according to Reviers (2006), Diatomaceae are widely distributed and may colonize all types of aquatic environments, Reynolds et al. (1994) states that the richness of Diatomaceae may be affected by water flow, intensity of light on the river, high nutrient availability, water quality and herbivory. This is due to the fact that species of Diatomaceae are fast growing organisms, especially in conditions of high nitrogen concentration, and to their status as opportunistic or colonizing algae ( $\mathrm{r}$ - and C-strategists, respectively) (Reynolds 1984; Sommer 1988). The above facts corroborate the results of the present study since the greatest richness of Diatomaceae occurred at P1, a site close to the source of the Tigre River and a site with low water flux, many stones, and scant shade, but a high degree of electrical conductivity.

Among the Diatomaceae with the highest occurrence frequencies, Melosira varians and Cymbella are associated with slow water flow due to their weak fixing structure and their preference for habitats with high luminosity (Hermany 2005). Maier \& Rott (1988) and Salomoni et al. (2006) underscored that Nitzschia palea, Achnanthidium minutissimum, Navicula cryptocephala and Ulnaria ulna are widely distributed species and are generally dominant in eutrophic environments. Moreover, Gomphonema parvum has been classified by Van Dam et al. (1994) and Lobo et al. (2002) as a moderately pollution-tolerant species. On the other hand, the ubiquitous genus Aulacoseira is the most successful of all the centric Diatomaceae, being greatly abundant in the plankton of lakes, reservoirs and large rivers (Wetzel 2011).

Green algae (Chlorophyceae) form the second most diverse group of the floristic composition of the studied rivers. According to Silva et al. (2009), Chlorophyceae encompasses some of the most widely distributed phytoplankton groups, occurring in all types of continental waters, whereas Luzia (2009) reports that they typically occur in rivers, lakes and shallow reservoirs with turbulence. These observations corroborate the results of current study since the greatest richness of Chlorophyceae occurred at the sampling sites P8 and P2, which are shallow and with few rapids. According to Peres \& Senna (2000), Chlorophyceae survive in very different environments, ranging from slightly polluted waters to highly eutrophyzed environments, and exhibit several survival strategies due to their great diversity.

In the present study, $\beta$-diversity proved to be moderate ( $\beta-1$ ranged between 24 and 38\%) and revealed a relatively low level of heterogeneity in the species of the sampled stretches. Dissimilarities may be found among stretches of the same river and stretches of the two rivers, since other environmental characteristics may affect phytoplankton composition. These environmental characteristics may include either different limnological features of lakes, as registered by Nogueira et al. (2008) when they estimated the three diversity components (alpha, beta, gamma) of the four urban lakes in the municipality of Goiânia GO Brazil, 
or interference by/with flood cycles (Nabout et al. 2007) or even the environment's trophic degree (Pires 2014). Consequently, the hypothesis regarding beta-diversity tested in by the present research is rejected since no significant co-relationship between the results has been observed.

The similarity analysis of species composition among sample sites found a co-phenetic coefficient of 0.86 , revealing a good representation of the actual distances between genotypes (Sokal \& Rohlf 1962). The dendrogram indicated that stretches without forest protection (P1, P2 and P7) were dissimilar from sites with extensive or total forest protection (P3, P4, P5), and sites P6, P8 and P9 had a composition that differed widely from the other sampled stretches. The classification shows that community composition can be affected by local environmental variables. Group 1, with approximately $78 \%$ similarity, was composed of only stream stretches with no forest protection. The above indicates that the removal of riparian vegetation increased the erosion of river-banks, thereby substituting the biota and changing the functional dynamics. The ecosystem did not remain predominantly heterotrophic, in which allochthonous energy is derived from leaves from riverside vegetation, but became a predominantly autotrophic ecosystem. In this case, the removal of riparian vegetation and, consequently, a greater penetration of light, benefitted autochthonous energy related to the algae of the streams (Novaes 2010).

Group 2 , with approximately $65 \%$ similarity, was composed of forest-protected stretches of the Tigre River (P3 is partially protected; P4 and P5 are totally protected). Consequently, there was low alpha-diversity due to the low concentration of chlorophyll-a, which is associated with canopy density and shading of the river margins of the stretches. Luminosity is one of the factors that can limit the rate of development of a phytoplankton community (Silveira 2004; Tundisi \& Matsumura-Tundisi 2008). Algae inserted in ecosystems with scant light must adapt to such conditions by improving their photosynthetic capacity with cells featuring great pigment amounts or by speeding their life cycle (Reynolds et al. 1994; Soares et al. 2007).

The stretches P6, P8 and P9 differed from all the other stretches (Groups 1 and 2), and with no similar composition among themselves. Since P6 and P9 lie at the mouths of the rivers where they empty into reservoirs, they are lotic to lentic transition environments. The two sites had low similarity, although they had the highest cyanobacteria concentrations. Cyanobacteria are organisms that exhibit ecological plasticity since they grow in almost all aquatic and land media, and are distributed throughout the planet and may be the most widespread photosynthetic organisms with regard to habitat (Badger et al. 2006; Melcher 2007). These organisms are sensitive to nutrient availability, and often bloom in eutrophyzed environments, thereby causing serious environmental changes and putting public health at risk due to the production of toxins (Yunes et al.1996; Ferrão-Filho et al. 2002).
A high concentration of chlorophyll-a, an indirect indication of algal biomass, could be perceived at site P9. Increase in algal biomass at this specific site may be associated with several factors, but mainly greater biological activity that usually occurs during the months with higher temperatures, hydraulic characteristics (less water movement due to the lotic-lentic transition environment), and the features of the hydrographic basin in which the river lies (Cunha \& Calijuri 2008).

The current investigation found high values of species richness for all of the sampled stretches, where beta-diversity, however, was moderate. A high degree of similarity between sampled stretches with only slight differences in species composition was observed among the sites along the gradient of the two rivers. Bacillariophyceae and Chlorophyceae were the most represented classes. Consequently, the hypothesis that river stretches protected by the forest will have lower species richness and greater beta-diversity than non-protected stretches was only partially supported. Protected sites did have lower species richness in comparison to non-protected stretches, however, beta-diversity did not differ significantly among these sites.

All of the 429 taxa registered in the present study are first records for the two study-rivers. This clearly illustrates the need for further floristic studies of larger streams and rivers in remote areas of the state of Santa Catarina, Brazil. Because of their rarity, some taxa could not be identified to the species level and, consequently, their distinguishing features could not be analyzed.

Since human activities are more and more intense in this specific region due to the development of towns and cities or due to the broadening of agricultural frontiers, the need for further study on the biodiversity of hundreds of other lotic environments of the region should be emphasized.

\section{Acknowledgements}

The authors would like to thank the Companhia Catarinense de Águas e Saneamento (CASAN) and Fundo de Apoio à Manutenção e ao Desenvolvimento da Educação Superior (FUMDES) for the fellowship to the first author. Thanks are also due to Unochapecó for funding this research, and to the Instituto Chico Mendes de Conservação da Biodiversidade (ICMBio).

\section{References}

An SS, Friedel T, Hegewald E. 1999. Phylogenetic relationships of Scenedesmus and Scenedesmus - like coccoid green algae as inferred from ITS-2 rDNA sequence comparisons. Plantbiology 1: 418-428.

APHA - American Public Health Association. 2012. Standard methods for examination of water and wastewater. 22th. edn. Washington, EPS Group.

Azevedo MTP, Nogueira NMC, Sant'Anna CL. 1996. Criptógamos do Parque Estadual das Fontes do Ipiranga, São Paulo, SP. Algas, 8: Cyanophyceae. Hoehnea 23:1-38. 
Azevedo MTP, Sant'Anna CL 1999. Coelosphaerium evidenter marginatum, a new planktonic species of Cyanophyceae/Cyanobacteria from São Paulo State, Southeastern Brazil. Algological Studies 94: 35-43.

Azevedo MTP, Sant'Anna CL. 2003. Sphaerocavum a new genus of planktonic Cyanobacteria from continental water bodies in Brazil. Algological Studies 109: 79-92.

Badger MR, Price GD, Long BM, Woodger FJ. 2006. The environmental plasticity and ecological genomics of the cyanobacterial $\mathrm{CO}_{2}$ concentrating mechanism. Journal of Experimental Botany 27: 249-265.

Baselga A. 2010. Partitioning the turnover and nestedness components of beta diversity. Global Ecology and Biogeography 19: 134-143.

Buchheim M, Buchheim J, Carlston T, Braband A, Hepperle D, Krienitz L, Hegewald E, Wolf M. 2005. Phylogeny of the Hydrodictyaceae (Chlorophyceae): Inferences from rDNA Data. Journal Phycology 41: 1039-1054.

Castro AAJ, Bicudo CEM, Bicudo DC. 1991. Criptógamos do Parque Estadual das Fontes do Ipiranga, São Paulo, SP. Algas 2: Cryptophyceae. Hoehnea 18: 87-106.

Colwell RK. 2006. Estimate S - Statistical estimation of species richness and shared species from samples. Version 8.0 Persistent. http://www. purl.oclc.org/estimates.

Comas A. 1996. Las Chlorococcales dulciacuicolas de Cuba. Bibliotheca Phycologica, Band 99. Stuttgart, J. Cramer.

Cottingham KL, Carpenter SR. 1998. Population community, and ecosystem variates as ecological indicators: phytoplankton responses to whole lake enrichment. Ecological Applications 8: 508-530.

Cunha DGF, Calijuri, MDC.2008. Comparação entre os teores de matéria orgânica e as concentrações de nutrientes e metais pesados no sedimento de dois sistemas lóticos do Vale do Ribeira de Iguape, SP. Revista de Engenharia Ambiental 5: 24-40.

EPA - Environmental Protection Agency. 1997. Stream flow. Volunteer stream monitoring: a methods manual. Washignton, EPA. 1: 134-138.

Ferragut C, Lopes MRM, Bicudo DC, Bicudo CEM, Vercellino IS. 2005. Ficoflórula perifítica e planctônica (exceto Bacillariophyceae) de um reservatório oligotrófico raso (Lago do IAG, São Paulo). Hoehnea 32: 137-184.

Ferrão-Filho AS, Kozlowsky-Suzuki B, Azevedo SM. 2002. Accumulation of microcystins by a tropical zooplankton community. Aquatic toxicology 59: 201-208.

Gering JC, Crist TO, Veech JA. 2003. Additive partitioning of species diversity across multiple spatial scales: implications for regional conservation of biodiversity. Conservation Biology 17: 488-499.

Godinho LR. 2009. Família Scenedesmaceae no Estado de São Paulo: Levantamento florístico. PhD Thesis, Instituto de Botânica de São Paulo, Brazil.

Godinho LR, Comas AA, Bicudo CEM. 2010. Criptógamos do Parque Estadual das Fontes do Ipiranga, São Paulo, SP. Algas, 30: Chlorophyceae (família Scenedesmaceae). Hoehnea 37: 513-553.

Golterman HL, Clymo RS, Ohnstad MAM. 1978. Methods for physical and chemical analysis of freshwaters. 2nd edn. Oxford, Blackwell Scientific.

Hammer Ø, Harper DAT, Ryan PD. 2001. PAST: Paleontological statistics software package for education and data analysis. Palaeontologia Electronica 4:9.

Harrison S, Ross SJ, Lawton JH. 1992. Beta diversity on geographic gradients in Britain. Journal of Animal Ecology 62: 151-158.

Hegewald E. 1997. Taxonomy and phylogeny of Scenedesmus. Algae (Korean Journal of Phycology) 12: 235-246.

Hegewald E. 2000. New combinations in the genus Desmodesmus (Chorophyceae, Scenedesmaceae). Algological Studies 96:1-18.

Hegewald E, Hanagata N. 2000. Phylogenetic studies on Scenedesmaceae (Chlorophyta). Algological Studies 100: 29-49.

Hegewald E, Wolf M. 2003. Phylogenetic relationships of Scenedesmus and Acutodesmus (Chlorophyta, Chlorophyceae) as inferred from $18 \mathrm{~S}$ rDNA and ITS-2 sequence comparisons. Plant Systematics and Evolution 241: 185-191.

Hermany, G. 2005. Ecologia da comunidade de diatomáceas epilíticas de um sistema de rio de baixa ordem da região Hidrográfica do Guaíba: subsídios ao monitoramento ambiental de ecossistemas aquáticos sul brasileiros. Msc Thesis, Universidade Federal do Rio Grande do Sul, Brazil.
Hoek C, Mann D, Jahns HM. 1995. Algae: an introduction to phycology. Cambridge, Cambridge University Press.

Hoffmann L, Komárek J, Kaštovský J. 2005. System of cyanoprokaryotes (Cyanobacteria)- state in 2004. Algological Studies 117: 95-115.

Hüber-Pestalozi G. 1955. Das phytoplankton des Süsswassers: systematik und biologie: Euglenaceen. E. Schweizerbart'sche Verlagsbuchhandlung 16: 605p.

Huszar VLM, Silva LHS, Esteves FA. 1990. Estrutura das comunidades fitoplanctônicas de 18 lagoas da região do Baixo Rio Doce, Linhares, Espírito Santo, Brasil. Revista Brasileira de Biologia 50: 585-598.

Hutchinson GE, 1961. The paradox of the plankton. American Naturalist 95: $137-147$

Hutchinson GE, 1976. A Treatise on Limnology. Vol. II. Introduction to Lake Biology and the Limnoplankton. New York, John Wiley and Sons, Inc.

ICMBio. 2013. Instituto Chico Mendes de Conservação da Biodiversidade. Plano de Manejo da Floresta Nacional de Chapecó, Brasil.

Komárek J, Anagnostidis K. 1989. Modern approach to the classification system of cyanophytes, 4: Nostocales. Algological Studies 56:247-345.

Komárek J, Anagnostidis K. 1998. Cyanoprokaryota. 1.Teil Chroococcales. In: Ettl H, Gärtner G, Heynig H, Möllenhauer D. (eds.) Sübwasserflora von Mitteleuropa. Stuttgart, Gustav Fischer Verlag. p.1-548.

Komárek J, Anagnostidis K. 2005. Cyanoprokaryota. 2. Teil Oscillatoriales. In: Büdel B, Krienitz L, Gärtner G, Schagerl M. (eds.) Sübwasserflora von Mitteleuropa. Munique, Elsevier: Spektrum Akademischer Verlag. p. 759.

Komárek J, Azevedo MTP. 2000. Geitlerinema unigranulatum, a common tropical cyanoprokaryote from freshwater reservoirs in Brazil. Algological studies 99: 39-52.

Komárek J, Fott B. 1983. Chlorophyceae (Grünalgen), Ordung: Chlorococcales. In: Pestallozi GH, Heynig H, Mollenhauer D. (eds.) des Süßwassersflora Band (1). Jena, Gustav Fischer. p. 1-1044.

Komárkova-Legnerová J, Cronberg G. 1994. Planktic blue-green algae from lakes in South Scania, Sweden. Part I. Chroococcales. Algological Studies 72: 13-51.

Kopp MM, Souza VQ, Coimbra JLM, Luz VK, Marini N, Oliveira AC. 2007. Melhoria da correlação cofenética pela exclusão de unidades experimentais na construção de dendrogramas. Revista da Faculdade de Zootecnia Veterinaria e Agronomia 14: 46-53.

Krammer K, Lange-Bertalot H. 1986. Bacillariophyceae: Naviculaceae. In: Ettl A, Lange-Bertalot H. (ed.) Iconographia Diatomologica, annotated diatom micrographs. Stuttgart, Koeltz Scientific Books. p. 1-876

Krammer K, Lange-Bertalot H. 1988. Bacillariophyceae 2. Teil: Bacillariaceae, Epithemiaceae, Surirellaceae. In: Ettl H, Gerloff J, Heynig H, Mollenhauer D. (eds.) Susswasser Flora von Mitteleuropa. Stuttgart, Gustac Fischer Verlag. p. 1-610.

Krammer K, Lange-Bertalot H. 1991. Bacillariophyceae, Teil. 3: Centrales, Fragilariaceae, Eunotiaceae. In: Ettl H, Gerloff I, Heynig H, Mollenhauer D. (eds.) Süsswasserflora von Mitteleuropa. Stuttgart, Fischer. p. 1-576.

Krienitz L, Bock C. 2012. Present state of the systematics of planktonic coccoid green algae of inland waters. Hydrobiologia. Doi:10.1007/ s10750-012-1079-z.

Krienitz L, Hegewald E, Hepperle D, Wolf M. 2003. The systematics of coccoid green algae: $18 \mathrm{~S}$ rRNA gene sequence data versus morphology. Biologia 58: 437-446.

Lamparelli MC. 2004. Grau de trofia em corpos d'água do Estado de São Paulo: avaliação dos métodos de monitoramento. PhD Thesis, Universidade de São Paulo, Brazil.

Legendre P, Borcard D, Peres-Neto PR. 2005. Analyzing beta diversity: partitioning the spatial variation of community composition data. Ecological Monographs 75: 435-450.

Leland HV, Porter SD. 2000. Distribution of benthic algae in the upper Illinois River basin in relation to geology and land use. Freshwater Biology 44: 279-301.

Lepistö L, Holopainen A, Vuoristo H, 2004. Type-specific and indicator taxa of phytoplankton as a quality criterion for assessing the ecological status of Finnish boreal lakes. Limnologica 248: 236-248. 
Lewis MA, Weber DE, Stanley RS, Moore JC. 2001. Dredging impact on an urbanized Florida bayou: effects on benthos and algal-periphyton. Environmental Pollution 115: 161-171.

Lobo E, Leighton G. 1986. Estructuras comunitarias de las fitocenosis planctonicas de los sistemas de desembocaduras de rios y esteros de la zona central de Chile. Revista de Biologia Marina y Oceanografia 22: 1-29.

Lobo EA, Callegaro VLM, Bender EP. 2002. Utilização de algas diatomáceas epilíticas como indicadoras da qualidade da água em rios e arroios da Região Hidrográfica do Guaíba, RS, Brasil. Santa Cruz do Sul, Edunisc.

Luzia AP. 2009. Estrutura organizacional do fitoplâncton nos sistemas lóticos e lênticos da bacia do Tietê - Jacaré (UGRHI - TIETÊ -JACARÉ) e relação à qualidade da água e estado trófico. $\mathrm{PhD}$ Thesis, Universidade Federal de São Carlos, Brazil.

Magurran EA. 1988. Ecological diversity and its measurement, 2nd. edn. Princeton, Princeton University Press.

Maier M, Rott E. 1988. The effect of local waste-water inflows on the structure of diatom assemblages in fast-flowing streams. In: Simola H. (ed.) Proceedings of the 10th Symposium on Recent and Fossil Diatoms. Koenigstein, Koeltz Scientific Publishers. p. 553-561.

Mccune B, Mefford MJ. 1999. PC-Ord version 4. Oregon, MjM Software Design.

Melcher SS. 2007. Estudos morfológicos e moleculares de cianobactérias potencialmente tóxicas dos gêneros Aphanizomenon, Cylindrospermopsis e Raphidiopsis (Nostocales). PhD Thesis. Instituto de Botânica de São Paulo, Brazil.

Menezes M. 1994. Fitoflagelados pigmentados de quatro corpos d'água da região sul do município do Rio de Janeiro, RJ, Brasil. PhD Thesis, Universidade de São Paulo, Brazil.

Metzeltin D, Lange-Bertalot H. 1998. Tropical Diatoms of South America I: About 700 predominantly rarely known or new taxa representative of the neotropical flora. In: Lange-Bertalot H. (ed.) Iconographia Diatomologica. Vol. 5. Königstein, Koeltz Scientific Books. p. 1-695.

Metzeltin D, Lange-Bertalot H. 2007. Tropical Diatoms of South America II: Special Remarks on Biogeographic Disjunction. In: Lange-Bertalot H. (ed.) Iconographia Diatomologica. Vol. 18. Königstein, Koeltz Scientific Books. p.1-877.

Metzeltin D, Lange-Bertalot H, García-Rodriguez F. 2005. Diatoms of Uruguay - Compared with other taxa from South America and elsewhere. In: Lange-Bertalot H. (ed.) Iconographia Diatomologica Vol. 15. Königstein, Koeltz Scientific Books. p.1-695.

Monteiro DR, Melo CAFN, Alves SMAM, Paiva SR. 2009. Composição e distribuição do microfitoplâncton do rio Guamá no trecho entre Belém e São Miguel do Guamá, Pará, Brasil. Boletim do Museu Paraense Emílio Goeldi. Ciências Naturais 4: 341-351.

Munn MD, Black RW, Gruber SJ. 2002. Response of benthic algae to environmental gradients in an agriculturally dominated landscape. Journal of the North American Benthological Society 21: 221-237.

Nabout JC, Nogueira IS, Oliveira LG, Morais RR. 2007. Phytoplankton diversity (alpha, beta and gamma) from the Araguaia River tropical floodplain lakes (central Brazil). Hydrobiologia 575: 455-461.

Nogueira IS. 1991. Chlorococcales sensu lato (Chlorophyceae) do município de Rio de Janeiro e arredores, Brasil: inventário e considerações taxonômicas. Msc Thesis, Universidade Federal do Rio de Janeiro, Brazil.

Nogueira IS, Nabout JC, Oliveira JE, Silva KD. 2008. Diversidade (alfa, beta e gama) da comunidade fitoplanctônica de quatro lagos artificiais urbanos do município de Goiânia, GO. Hoehnea 35: 219-233.

Nogueira IS, Nabout JC, Ibañez MSR, Bourgoin LM. 2010. Determinants of beta diversity: the relative importance of environmental and spatial processes in structuring phytoplankton communities in an Amazonian floodplain. Acta Limnologica Brasiliensia 22: 247-256.

Novaes MC. 2010. A integridade ambiental e o tamanho do riacho afetam a diversidade e a abundância de Trichoptera (Insecta) associada ao substrato rochoso em riachos de montanha? PhD Thesis, Universidade de São Paulo, Brazil.

Paerl HW, Huisman J. 2009. Minireview climate change: A catalyst for global expansion of harmful cyanobacterial blooms. Environmental Microbiology Reports 1:27-37.
Peres AC, Senna PAC. 2000. Chlorophyta da Lagoa do Diogo. In: Santos JE, Pires JSR. (eds.) Estudos Integrados em Ecossistemas: Estação Ecológica de Jataí. São Carlos, RiMa 2. p. 469-481.

Pires DA. 2014. Diversidade (alfa, beta e gama) da comunidade fitoplanctônica de quatro reservatórios do Alto Tietê, Estado de São Paulo, com diferentes graus de trofia. Msc Thesis, Instituto de Botânica de São Paulo, Brazil.

Ramos GJP, Bicudo CEM, Neto AG, Moura CWN. 2012. Monoraphidium and Ankistrodesmus (Chlorophyceae, Chlorophyta) from Pantanal dos Marimbus, Chapada Diamantina, Bahia State, Brazil. Hoehnea 39: 421-434

Reviers B. 2006. Biologia e filogenia das algas. Tradução Iara Maria Franceschini. Porto Alegre, ARTMED.

Reynolds CS. 1984. The Ecology of Freshwater Phytoplankton. Cambridge, Cambridge University Press.

Reynolds CS. 2006. Ecology of Phytoplankton. Cambridge, Cambridge University Press.

Reynolds CS, Descy JP, Padisák J. 1994. Are phytoplankton dynamics in rivers so different from those in shallow lakes? Hydrobiologia, 289: 1-7.

Rodrigues LC, Train S, Bovo-Scomparin VM, Jati S, Borsalli, CCJ, Marengoni E. 2009. Interannual variability of phytoplankton in the main rivers of the Upper Paraná River floodplain, Brazil: influence of upstream reservoirs. Brazilian Journal of Biology 69: 501-516.

Rodrigues LL, Sant'Anna CL, Tucci A. 2010. Chlorophyceae das Represas Billings (Braço Taquacetuba) e Guarapiranga, SP, Brasil. Revista Brasileira Botânica 33: 247-264.

Rodrigues SC. 2004. Estudo comparativo da estrutura da comunidade fitoplanctônica na foz dos rios formadores do Delta do Jacuí. Msc Thesis, Universidade Federal do Rio Grande do Sul, Brazil.

Rosini EF, Sant'Anna CL, Tucci A. 2012. Chlorococcales (exceto Scenedesmaceae) de pesqueiros da Região Metropolitana de São Paulo, SP, Brasil: levantamento florístico. Hoehnea 39: 11-38.

Rosini EF, Sant'Anna CL, Tucci A. 2013a. Scenedesmaceae (Chlorococcales, Chlorophyceae) de pesqueiros da Região Metropolitana de São Paulo, SP, Brasil: levantamento florístico. Hoehnea 40: 661-678.

Rosini EF, Sant'Anna CL, Tucci A. 2013b. Cyanobacteria de pesqueiros da região metropolitana de São Paulo, Brasil. Rodriguésia 64: 399-417.

Round FE. 1971. The taxonomy of the Chlorophyta II. British Phycological Journal 6: 235-264.

Salomoni SE, Rocha O, Callegaro VL, Lobo EA. 2006. Epilithic diatoms as indicators of water quality in the Gravatai river, Rio Grande do Sul, Brazil. Hydrobiologia 559: 233-246.

Sant'Anna CL. 1984. Chlorococcales (Chlorophyceae) do Estado de São Paulo, Brasil. Bibliotheca Phycologica 67: 1-348.

Sant’Anna CL, Azevedo MTP, Senna PAC, Komárek J, Komárková J. 2004. Planktic Cyanobacteria from São Paulo State, Brazil: Chroococcales. Revista Brasileira de Botânica 27: 213-227.

Sant'Anna CL, Azevedo MTP, Sormus L. 1989. Fitoplâncton do Lago das Garças, Parque Estadual das Fontes do Ipiranga, São Paulo, SP, Brasil: Estudo Taxonômico e Aspectos Ecológicos. Hoehnea 16:89-131.

Sant'Anna CL, Tucci A, Azevedo MTP, et al. 2012. Atlas de Cianobactérias e Microalgas de águas continentais Brasileiras. São Paulo, Instituto de Botânica de São Paulo.

Silva MH, Silva-Cunha MGG, Passavante JZO, Grego CKS, Muniz K. 2009. Estrutura sazonal e espacial do microfitoplâncton no estuário tropical do rio Formoso, PE, Brasil. Acta Botanica Brasilica 23: $355-368$.

Silveira MP. 2004. Aplicação do biomonitoramento para avaliação da qualidade da água em rios. Embrapa Meio Ambiente, Brasil.

Soares MCS, Huszar VLM, Roland F. 2007. Phytoplankton dynamics in two tropical rivers with different degrees of human impact (southeast Brazil). River research and applications 23: 698-714.

Sokal RR, Rohlf FJ. 1962. The comparison of dendrograms by objective methods. Taxon 33-40.

Sommer U. 1988. Growth and survival strategies of planktonic diatoms. Growth and reproductive strategies of freshwater phytoplankton. Cambridge, Cambridge University Press. 227-260. 
Stirling G, Wilsey B. 2001. Empirical relationships between species richness, evenness, and proportional diversity. The American Naturalist 158: 286-299.

Tell G, Conforti V. 1986. Visitación. Euglenophyta pigmentadas de la Argentina. J. Cramer in der Gebrüder Borntraeger Verlagsbuchhandlung.

Ternus RZ, Souza-Franco GMD, Anselmini MEK, Mocellin DJC, Dal Magro J. 2011. Influence of urbanization on water quality in the basin of the upper Uruguay River in western Santa Catarina, Brazil. Acta Limnologica Brasiliensia 23: 189-199.

Tucci A, Sant'Anna CL, Gentil RC, Azevedo MTP. 2006. Fitoplâncton do Lago das Garças, São Paulo, Brasil: um reservatório urbano eutrófico. Hoehnea 33: 147-175.

Tundisi JG, Matsumura-Tundisi T. 2008. Limnologia. São Paulo, Oficina de textos.
Van Dam H, Mertens A, Skindelam J. 1994. A coded checklist and ecological indicator values of freshwaters diatoms from Netherlands. Netherland Journal of Aquatic Ecology 28:117-133.

Vannote RL, Mishall GW, Cummins KW, Sedell JR, Cushing CE. 1980. The River Continuum Concept. Canadian Journal of Fisheries and Aquatic Sciences 37: 130-137.

Wetzel CE. 2011. Biodiversidade e distribuição espacial de diatomáceas (Bacillariophyceae) na bacia hidrográfica do Rio Negro, Amazonas, Brasil. PhD thesis. Instituto de Botânica de São Paulo, Brazil.

Whittaker RH. 1972. Evolution and measurement of species diversity. Taxon 21: 213-251.

Yunes JS, Salomon PS, Matthiensen A, Beattie KA, Raggett SL, Codd GA. 1996. Toxic blooms of cyanobacteria in the Patos Lagoon Estuary, southern Brazil. Journal of Aquatic Ecosystem Health 5: 223-229. 